Исаев Ю.н.

БУ ЧР ДПО «Чувашский республиканский институт образования» Министерства образования и молодежной политики Чувашской Республики,

Чебоксары, Российская Федерация.

(D) ORCID: https://orcid.org/0000-0002-6354-4676, e-mail: isaev2828@yandex.ru

Резюме: представлено выступление ректора БУ ЧР ДПО «Чувашский республиканский институт образования» Минобразования Чувашии, доктора филологических наук Исаева Ю.Н. на республиканском форуме учителей русского языка и литературы Чувашской Республики. Рассмотрено положение русского языка в отечественной и мировой тенденциях с точки зрения универсальных показателей, дающих цельное представление о сложившейся ситуации с русским языком в стране и в мире. Продемонстрированы результаты обучения русскому языку в общеобразовательных организациях Чувашской Республики.

Ключевые слова: русский язык, преподавание и изучение русского языка, билингвы, Основной государственный экзамен, Единый государственный экзамен.

Для цитирования: Исаев Ю.Н. Русский язык в Чувашской Республике // Развитие образования. - 2021. - Т. 4, №3. - C. 56-59. DOI:10.31483/r-99424.

\title{
Russian Language in the Chuvash Republic
}

\author{
BI of FVE "Chuvash Republican Institute of Education" of the Ministry of Ec \\ Cheboksary, Russian Federation. \\ (iD ORCID: https://orcid.org/0000-0002-6354-4676, e-mail: isaev2828@yandex.ru
}

\begin{abstract}
The speech of the rector of the BI of FVE "Chuvash Republican Institute of Education of the Ministry of Education of Chuvashia", doctor of philological sciences Isaev Yu. N. at the republican forum of teachers of Russian language and literature of the Chuvash Republic is presented. The article considers the position of the Russian language in the domestic and world trends from the point of view of universal indicators that give a complete picture of the current situation with the Russian language in the country and in the world. The results of teaching the Russian language in general education organizations of the Chuvash Republic are demonstrated.
\end{abstract}

Keywords: Russian language, teaching and learning of the Russian language, bilinguals, the basic state examination, the Unified State Exam

For citation: Isaev Y.N. (2021). Russian Language in the Chuvash Republic. Razvitie obrazovaniya = Development of education, 4(3), 56-59. (In Russ.) DOI 10.31483/r-99424.

\section{Чӑваш Республикинче усӑ куракан вырӑс чӗлхи}

\section{Исаев Ю.Н.}

ЧР ХПВ Чӑваш Республикин Вӗренӱ тата с̧амрӑксен политики министерствин «Чӑваш Республикин вӗренӱ институчӗ» БУ,

Шупашкар хули, Рас̧с̧ей Федерацийӗ.

(iD) ORCID: https://orcid.org/0000-0002-6354-4676, e-mail: isaev2828@yandex.ru

\begin{abstract}
Аннотаци: ЧР ХПВ Чӑваш Республикин Вӗренӱ тата с̧амрӑксен политики министерствин «Чӑваш Республикин вӗренӱ институчӗ» БУ ректоре̌н Ю.Н. Исаев республика форумӗнче чӑваш Республикин вырӑс чӗлхипе литература вӗрентекенӗсен "чӑваш республики вӗренӳ институчӗ" сӑмах тухса каланине тӑратнӑ. Вырӑс че̌лхи хамӑр с̧ӗр-шывпа тӗнче туртӑмӗнче мӗнле вырӑн йышӑннине универсал кӑтартусем с̧ине таянса пӑхса тухнӑ. Вӗсем вырӑс чӗлхипе с̧ыхӑннӑ лару-тӑру с̧ӗр-шывӑмӑрта тата те̌нчере мӗнлерех пулнине пӗтӗмӗшлӗн курма май парас̧с̧ӗ. Вырӑс чӗлхине Чӑваш Республикин пӗтӗмӗшле пӗлӱ паракан организацийӗсенче мӗнле вӗрентнине кӑтартнӑ.
\end{abstract}

Tӗп сӑмахсем: вырӑс чӗлхи, вырӑс чӗлхине вӗрентни тата тӗпчени, ик чӗлхе пӗлекенсем, Патшалӑхӑн тӗп экзаменӗ, Патшалӑхӑн пӗрлехи экзаменӗ

Цитатӑлама: Исаев Ю.Н. Чӑваш Республикинче усӑ куракан вырӑс чӗлхи // Вӗренӳ аталанӑвӗ. -2021. - Т. 4, №3. C. 56-59. DOI:10.31483/r-99424.

Русский язык является одним из 12 мировых языков и занимает 5-е место как язык международного общения, пропустив вперёд английский, испанский, французский и китайский языки.

Комплексное представление о положении русского языка в мире могут дать Индекс глобальной конкурентоспособности (ГК-Индекс) и Индекс устойчивости русского языка в странах постсоветского пространства (УС-Индекс), предложенные экспертами Государственного института русского языка им. А.С. Пушкина [1].
По числу говорящих русский язык занимает 8-е место в мире с показателем 258 млн. человек, уступая английскому (1,268 млрд.), китайскому (1,12 млрд.), хинди (637 млн.), испанскому (538 млн.), французскому (277 млн.), арабскому (274 млн.) и бенгали (265 млн.).

Русский язык является официальным или рабочим языком в 15 из 23 крупнейших международных организациях (таких, как Организация Объединенных Наций $(\mathrm{OOH})$ Всемирная организаций здравоохранения (BO3), Международное агентство по атомной энергии 
(МАГАТЭ), Организация Объединенных Наций по вопросам образования, науки и культуры (ЮНЕСКО) и др.) и занимает 4-е место после английского, французского и испанского языков.

В мониторинге по числу публикаций в двух ведущих научных международных базах Scopus и Web of Science и по количеству СМИ русский язык расположился на 5-й и 7-й позициях соответственно. По числу пользователей информационно-телекоммуникационной сети Интернет и по количеству сайтов в Интернете, использующих данный язык в качестве языка контента, русскому языку принадлежат 10-е и 2-е места.

Таким образом, в соответствии с Индексом глобальной конкурентоспособности (ГК-Индекс) русский язык занимает 5-е (из 12) место, значительно уступив английскому, испанскому, французскому и китайскому языкам, но обойдя португальский, арабский, и немецкий языки.

Индекс устойчивости русского языка в странах постсоветского пространства (УС-Индекс), рассчитанный по трем параметрам, учитывает статус русского языка в государственно-общественной сфере, в сфере образования и в научной коммуникации. В соответствии с УС-Индексом русский язык наиболее устойчив в Республике Беларусь и наименее устойчив в Республике Грузия.
Положение русского языка в отечественной тенденции можно проследить на примере Чувашской Республики, являющейся одним из национальных субъектов Российской Федерации.

По состоянию на 01 января 2021 года, численность населения Чувашской Республики составляет 1207875 человек. Здесь проживают представители 128 национальностей, среди них чуваши (68\%), русские $(27 \%)$, татары, марийцы, мордва (4\%) (рис. 1).

Итоги переписи 2010 года показали, что из 44 языков, которыми в той или иной степени владеют все респонденты, русским языком владеют 99\% опрошенных, используют в повседневной жизни 81,6\%, считают родным 49,2\% участников [2] (рис. 2)/

В Чувашской Республике созданы все условия для преподавания и изучения русского языка как одного из государственных языков субъекта Российской Федерации (вторым государственным языком республики является чувашский язык) [3].

По данным Министерства образования и молодежной политики Чувашской Республики, русский язык и литературу преподают в общеобразовательных организациях 1070 педагогов, из них с высшим образованием - 98,9\%, имеющие высшую квалификационную категорию - 37,7\%, молодых педагогов до 35 лет - 14\%, педагогов с 20 -летним стажем и более $-70,0 \%$ (рис. 3 )

\section{Численность населения Чувашской Республики на 01.01.2021 года составляет 1207875 чел.}

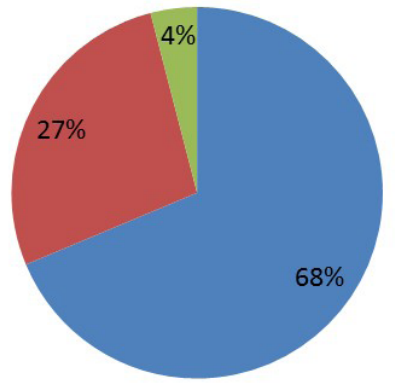

Puc. 1.

Fig. 1 .

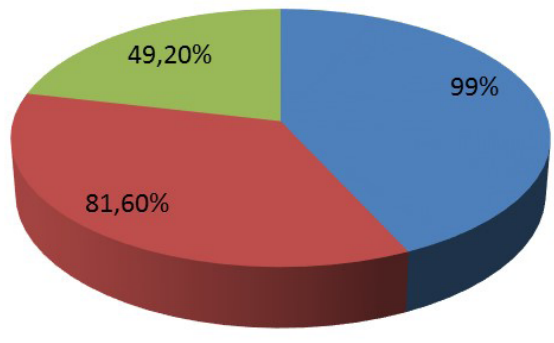

Чуваши $68 \%$

Русские $27 \%$

Татары, марийцы, мордва 4\%

Puc. 2.

Fig. 2. 


\section{УЧИТЕЛЯ РУССКОГО ЯЗЫКА И ЛИТЕРАТУРЫ}

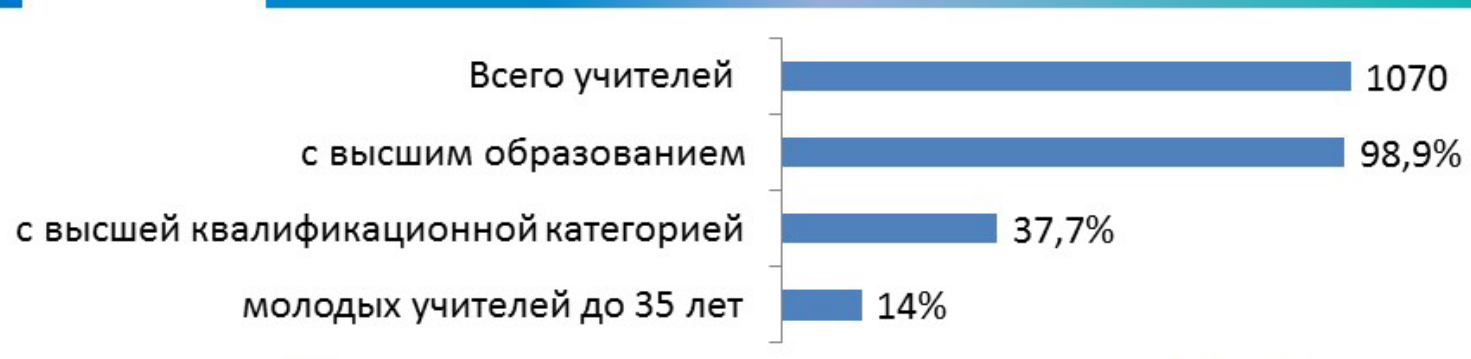

Распределение по стажу педагогической работы

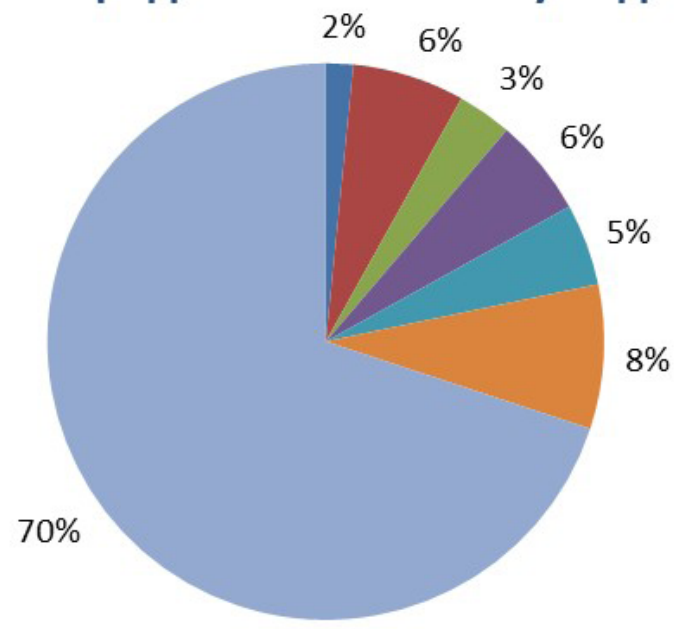

0 лет

до 3 лет

3-5 лет

п-10 лет

10-15 лет

15-20 лет

20 лет и более

Puc. 3 .

Fig. 3 .

В соответствии с Федеральными государственными образовательными стандартами основного общего и среднего общего образования русский язык входит в обязательную часть основной образовательной программы и является обязательным предметом Государственной итоговой аттестации для выпускников 9 и 11 классов.

Начиная с 2014 года, доля выпускников Чувашской Республики, успешно (выше минимального порога) сдавших русский язык в форме Основного государственного экзамена (ОГЭ), в среднем составляет 98,5\% ${ }^{1}$, в форме Единого государственного экзамена (ЕГЭ) $99,8 \%$.

Доля высокобалльников с 2014 по 2021 гг. по русскому языку в среднем по региону составляет $31,8 \%$.
Наибольшее количество участников, набравших 100 баллов за ЕГЭ по русскому языку, в 2016 году составило 41 человек, наименьшее в 2017 году - 17 человек; стабильно ровные показатели наивысшего результата можно наблюдать по итогам ЕГЭ 2018, 2019, 2020 и 2021 гг. - 30 и более человек.

Русский язык является родным языком в Чувашской Республике не только для этнических русских, но и для большей части населения билингвов. Благодаря таким мероприятиям, как форум, организованный при поддержке Ассоциации учителей литературы и русского языка (АССУЛ), осуществляется популяризация русского языка в Чувашской Республике, неуклонно возрастает интерес к его изучению.

\footnotetext{
${ }^{1}$ Напомним, что в 2020 году ОГЭ был полностью отменен.
}

\section{Список литературы}

1. Индекс положения русского языка в мире: индекс глобальной конкурентоспособности (ГК-Индекс), индекс устойчивости в странах постсоветского пространства (УС-Индекс) / сост. А.Л. Арефьев, Д.А. Горбатова, В.А. Жильцов, С.Ю. Камышева, Е.В. Колтакова, И.А. Маев, М.А. Осадчий, М.Н. Русецкая, А.С. Хехтель, М.И. Яскевич; под ред. М.А. Осадчего. - М.: Государственный институт русского языка им. А.С. Пушкина, 2020. - 34, [2] с.

2. Исаев Ю.Н. Состояние и перспективы развития системы образования Чувашской Республики / Ю.Н. Исаев // Образование: теория, методология, опыт: монография / гл. ред. Ж.В. Мурзина. - Чебоксары: ИД «Среда», 2019. - С. 5-29.

3. Исаев Ю.Н. Обеспечение условий для изучения и использования языков народов Российской Федерации в образовательных организациях Чувашской Республики / Ю.Н. Исаев // Актуальные вопросы исследования и преподавания родных языков и литератур: материалы Междунар. науч.-практ. конф. (Чебоксары, 16 ноября 2019 г.) / редкол.: Ж.В. Мурзина [и др.]. - Чебоксары: ИД «Среда», 2020. - С. 227-229 
References

1. Osadchego, M.A., Arefev, A.L., Gorbatova, D.A., Zhiltsov, V.A., Kamysheva, S.Iu., Koltakova, E.V., Maev, I.A., Osadchii, M.A., Rusetskaia, M.N., \& Khekhtel, A.S. (2020). Indeks polozheniia russkogo iazyka v mire: indeks global'noi konkurentosposobnosti (GK-Indeks), indeks ustoichivosti v stranakh postsovetskogo prostranstva (US-Indeks). Iaskevich; Pushkina.

2. Isaev, Iu.N. (2019). Current State and Development Prospects of the Chuvash Republic Educational System. Education: theory, methodology, experience: monograph, 5-29. Cheboksary: ID "Sreda".

3. Isaev, Iu.N. (2020). Obespechenie uslovii dlia izucheniia i ispol'zovaniia iazykov narodov Rossiiskoi Federatsii v obrazovatel'nykh organizatsiiakh Chuvashskoi Respubliki. Relevant questions on investigation and teaching of the native language and literature, 227-229. Cheboksary: ID "Sreda".

\section{Информация об авторе}

Исаев Юрий Николаевич - д-р филол. наук, ректор БУ ЧР ДПО

«Чувашский республиканский институт образования» Министерства образования и молодежной политики Чувашской Республики, Чебоксары, Российская Федерация.
Information about the author

Yuriy N. Isaev - doctor of

philological sciences, rector of BI of

FVE "Chuvash Republican Institute

of Education of the Ministry of

Education of Chuvashia",

Cheboksary, Russian Federation.
Автор с̧инчен пёлтерни Исаев Юрий Николаевич афилол. ӑслӑлӑхе̌н д-ре̌, ЧЧР ХПВ Чӑваш Республикин Вӗренӱ тата с̧амрӑксен политики министерствин «Чӑваш Республикин вёренӱ институче̌» БУ ректоре̌, Шупашкар, Рас̧сей Федерацийӗ.

Поступила в редакцию / Received / Редакцие с̧итнӗ 03.08.2021

Принята к публикации / Accepted / Пичетлеме йышӑннӑ 23.09.2021

Опубликована / Published / Пичетленсе тухнӑ 28.09.2021 